\title{
The Post-Soviet Syndrome of Ukrainian Education: Administrative Issues
}

\author{
Lunyachek Vadim Eduardovich \\ Ukrainian Engineering Pedagogics Academy \\ 61003, Kharkiv, 16 Universitetska St. \\ cross $^{\text {ref }}$ http://dx.doi.org/10.5755/j01.ppaa.16.1.18015
}

\begin{abstract}
The paper considers the influence of the post-Soviet past on modern processes in Ukrainian education. It also contains materials of opinion surveys of education managerial personnel held during the last ten years and analyzes the dynamics of their views on the influence of political factors on personnel appointments in education, etc. The research emphasizes democratization and professional development of the process of appointment of managerial personnel in education, the necessity of applying new economic techniques under the condition of decentralization in educational administration, fundamental changes of the managerial and pedagogical staff, etc.
\end{abstract}

Keywords: administrational decentralization, educational administration, educational reforms, managerial personnel/ staff, post-Soviet syndrome, totalitarianism.

Raktažodžiai: administracine decentralizacija, švietimo administravimas, švietimo reformos, vadybinis personalas/ darbuotojai, posovietinis sindromas, totalitarizmas.

\section{Introduction}

Relevance of research and problem statement. The latest history of the independent Ukraine covers 25 years. The period of the formation of new state management has been contradictory and difficult. Education is no exception. The development of a managerial system is more declarative than effective or similar to the best international practices. Analyzing the problem systematically it should be mentioned that problems in the management system directly affect the development of the educational system as a whole. One of such problems is the influence of consequences of the country's totalitarian past, corresponding mentality and stereotypes in working habits of most managers. The paper is a result of the author's research that has been conducted in the last ten years and has included the Ukraine's 
managerial personnel in education. The paper attempts to analyze the reasons of low effectiveness of reforms in Ukrainian education as a result of the post-Soviet syndrome in work with managerial and pedagogical staff.

Literature review. Theoretical and methodological aspects of Ukrainian educational administration have found their reflection in a wide range of scientific publications. The works published on this theme before 1991 (Ye. Bereznyak, V. Bondar, B. Kobzar and others) predominantly reflect the approaches typical of classical School Organization and Management as a branch of Soviet pedagogy.

Ukraine's gaining of independence in 1991 boosted further research of this issue taking into account conclusions of both Ukrainian (V. Bereka, L. Vashchenko, L. Danylenko, M. Darmansky, G. Yelnikova, T. Lukina, V. Maslov, N. Ostroverkhova, Ye. Pavlyutenkov, A. Sbruyeva, T. Sorochan, Ye. Khrikov, and others) and foreign scientists (T. Bush, P. Silver, K. Evers, W. Rast, A. De Caluve, E. Marks, M. Petri and others). In this period, the ideas of effective schools were widely referred to in research of Ukrainian scientists (S. Perki, M. Smith, D. Livayn, L. Lizott, J. Shirins, K. Cotton, P. Semmons, J. Hillman, P. Mortimore and others) [10].

At the same time, Ukrainian researchers did not pay due attention to the influence of totalitarianism on educational genesis. In this connection we should mention O. Lyubar's and other authors' works since they emphasize that Ukrainian schools were already obedient instruments of a totalitarian system in the 1940s. Having survived the anarchy of collectivization period, the Holodomor of 1932-1933, repressions and the persecution of the intelligentsia, it became an obedient mouthpiece of anti-national government politics. This role remained unchanged in the post-war society [17, p. 366]. Profound analysis of consequences of totalitarianism in Ukraine can be found in a collection of academic papers by international authors, including Z. Bzrezinski, Ya. Bzrezinski and Ye. Bystrytskyi who describe the genesis of post-communist societies [2].

Under such conditions, the head of any educational institution or an educational administration body became a mouthpiece of the ruling communist party within the frameworks of the applying a cruel command-and-control system, which immediately influenced aims setting and educational administration. A teacher was understood by administrative bodies to be an executor of the government's will as reflected in corresponding party directives. These tendencies have had considerable influence on the development of education in Ukraine till nowadays.

Among the researchers who have studied the above mentioned issue, V. Burdyak and M. Lazhykha have made considerable contribution in analysis of transformation in education and culture in the post-communist republic of Bulgaria [1; 5]. Another valuable source is a collection of papers on post-communist transformations in the Baltic countries [18]. The research by O. Shelomovska also provides relevant facts on state management in higher education in post-communist countries of the European Union. Some of the mechanisms mentioned by the author concern all levels of education because they were originally formed as tools of influence on all education [19]. Applying the method of analogy, the thesis of the research can be interpreted in 
present day Ukraine.

Having thoroughly reviewed scientific literature, we should claim that most of the researchers study development and perspectives of education in the Ukraine, and its administration in particular, without considering consequences of the Soviet totalitarian past, which prevent them from fully understanding the reasons of existing problems and ways of their solution. A whole range of thoroughly developed projects and programs has reached the objectives just partially set. This can be accounted for by mentality and stereotypes in looking at the problem from the perspective of performers who are actually representatives of the political system which has become a thing of the past.

Currently, the issues mentioned above have been widely considered not so much in scientific specialized papers and monographs, but among expert society in electronic sources. In this context, one should refer to works and materials of scientific, statistic and publicistic character found on the portal of public experts "Educational Policy" which is supported by the Committee on Education and Science of the Verkhovna Rada of Ukraine and the international foundation "Vidrodzhennya" ("Revival"). To begin with, these are works by V. Belyy, V. Bakhrushin, V. Hromovyi, L. Parashchenko, Y. Fedorchenko and others [3]. Besides, the cycle of V. Hromovyi's works entitled "Let's liquidate marasmus in school education" is worth attention [4].

Setting the objective. The objective of this paper is to prove that the low efficiency of reforms in the Ukrainian educational system is a result of an outdated administrative system which still remains politically-biased and top-down, as a result of the country's totalitarian past, which is reflected in staff policy in education.

Discussion. We have continually been examining development of Ukrainian education, including crisis conditions, in previous works [12]. The way of Ukraine to Europe is intricate and extended. It is complicated by external military aggression, corruption, low level of state management which influences all the spheres of life, including education.

\section{Personnel policy in the years of independence}

The recent history of Ukrainian education is a set of reforms which permanently flow one into another, sometimes contradicting each other and thus failing to achieve a desired or a declared result [16]. There is an impressive number of documents which have been published on the state level on this theme. It is the State Program "Education" ("Ukraine of the 21st century") (1993), the Concept of Ukrainian Distance Education Development (2000), the Concept of Compulsory Secondary Education (12-year school) (2001), the National Doctrine of Education Development (2002), the State Program "Teacher" (2002), the Concept of Subject-Oriented Education in High School (2003, 2009), etc. Only within the last 5 years the following documents have been published in the context of Ukrainian education reforms: the National Strategy for Education Development for 2012-2021; the Concept of Subject-Oriented Education in High School (2013); the Strategy for 
Ukrainian High Education Reforms till 2020; the Concept of Ukrainian Education Development for 2015-2020; the Concept of The New Ukrainian School (2016), etc. Moreover, a certain number of projects and programs have been implemented through the decisions of The Cabinet of Ministers of Ukraine and through the orders validated by the Ministry of Education and Science of Ukraine, through positions reflected in the Decrees of the Presidents of Ukraine on issues of education and many other documents. Contradictions in these documents prevent the Verkhovna Rada of Ukraine from passing a new law «On Education», which is urgent since the law currently in force is morally outdated and fails to meet modern requirements [13].

It should be mentioned that none of these reforms has been successfully completed, and certain provisions of the above mentioned documents partially repeat the content of each other and are of declarative character, and do not provide strict mechanisms of realization in time. Analyzing the administrative aspect of the processes, since 2008 we have questioned the administrators of educational institutions using one and the same tool, which permits making certain scientific generalizations $[7 ; 8 ; 15]$.

First of all, the fact that the influence of the political factor on staff nominations in education remains essential should be stated. It is evident that in the period since 1991 during the presidency of L. Kravchuk (1991-1994) and L. Kuchma (1994-2005) the system of staff nominations of administrators in education was actually built on the classical soviet scheme of a nomenclature employee according to the questionnaire rate and the system of individual interviews with heads of the government and local government, administrators in education of various levels. However, this procedure partially allowed to take into account not only political loyalty of the candidates for administrative popsitions, but also their professional career. 2005 witnessed a political bacchanalia which was accounted for by political expediency (this immediately draws an analogy with the time of Stalin, with the only difference that everything was much stricter then). Contrary to the pedagogical community's expectations, the bacchanalia was initiated during the presidency of V. Yushchenko (2005-2010), who came to power on the wave of democratic aspirations of the Ukrainian nation but appeared to be not capable of implementing true political reforms, which resulted in V. Yanukovich's rise to power (2010-2014), further flourishing of reactionary forces and corruption and as a result caused the Revolution of Dignity, the attempts to change the political system and the elections of the new President of Ukraine P. Poroshenko in 2014.

\section{Results of opinion survey of managerial personnel in education}

At this point it is worth mentioning the materials of questioning managerial staff fluctuation in the system of secondary education taking heads of regional departments of education as an example since 1945 till V. Yushchenko's presidency. We defined the beginning of the 21 st century as staff crisis [15, p. 200-227]. The research was conducted in Kharkiv region of Ukraine among others. It was discovered that before 2000 the period of office of an administrator in education on the regional level was 5- 
19 years. After 2000 it substantially decreased up to two years on the average. The situation stabilized gradually after 2010 simultaneously with an increase in influence of the political factor on managerial personnel appointments. Permanent change of administrative staff was actually hindering provision of reforms with qualified managerial support. A significant number of the reforms was made public in 20002005, which was especially noticeable on the basic regional level.

In such a way, for example, the results of school headmasters' questioning in 2008-2010 concerning the influence of the political factor on personnel appointments indicate the importance of this factor. This was confirmed by $44.4 \%$ of school headmasters and $63.2 \%$ heads of regional departments of education. Herewith $22.2 \%$ of school headmasters hesitated with their answer.

There has been a sustainable positive tendency of decreasing the influence of the political factor when appointing managers in education only after the Revolution of Dignity, which can be traced in another questioning in 2014. The interviewees mentioned that the role of the political factor in appointments was important in $29.5 \%$ of cases. The number of interviewees who hesitated about the answer was $33 \%$. According to a poll in 2016, 25\% of the questioned school headmasters considered appointments in education sphere politically-biased. At the same time the percentage of respondents who hesitated about the answer remained high (38\%). Thus, in spite of certain positive dynamics, there is still an essential political component that influences managerial appointments in education, which does not contribute to democratization of education in Ukraine.

A survey of motives for managerial position occupation also demonstrated certain dynamics. In 2008-2010 the motives for occupying a secondary school headmaster position was a wish to change something for $38.9 \%$ of respondents, for $36.8 \%$ it was image, for $5.8 \%$ - financial motives. In 2014, $72.7 \%$ of respondents were motivated by a desire to change something, $49.3 \%$ were motivated by image, and $19.3 \%$ were motivated financially. In $2016,75 \%$ of the respondents also expressed desire to change something, $63 \%$ mentioned the image factor, and only $13 \%$ were driven financially. Thus, the growth of a sustainable tendency to change the education system in managerial personnel's wishes can be perceived as a fact, which could be on the whole connected with the process of democratic changes in the country.

As to the procedure of appointing managerial personnel in education, in 2008$201033 \%$ of the respondents believed that it should be done relying on the results of professional testing. In 2014 this percentage reached 42.3\%. In 2016, despite the growth of general understanding that it is vital to change the existing procedure of appointing managerial staff in education to $50 \%$, only $25 \%$ of the interviewees agreed to undergo a professional examination of applicants for managerial positions by means of testing technologies.

A significant drawback is the fact that completing a specialized Master's degree in Education Management in Ukraine has not become a necessary condition for appointing head of an educational institution or an education authority. We 
considered the question of training educational managers in Master's programs in Ukraine in previous works $[6 ; 9 ; 14]$.

\section{Reforms in education management - an urgent task}

Another important aspect of educational reforms in Ukraine is life-long education of managerial personnel. Before, further qualification training was mainly carried out by postgraduate pedagogical educational institutions - structures which appeared in the late $30 \mathrm{~s}$ of the 20th century at the height of totalitarianism in the Soviet Union. Nowadays there is diversification of postgraduate pedagogical education on the state level in Ukraine. A confirmation of the proper choice is the standpoint of $44 \%$ of the interviewed managers of educational institutions who do not want to upgrade as managers at the institute of postgraduate pedagogical education. They prefer other institutions of higher education which have a corresponding license and a more powerful scientific and pedagogical potential [11].

The surveys also estimated education managers' point of view about the influence of education management levels on quality improvement. Thus, in 20082010, most of the respondents thought that the state enjoyed the highest influence $64.7 \%$, the influence on regional level was $0 \%$, the level of an administrative region was $5.9 \%$, the level of an educational institution was $23.5 \%$.

In 2014 the state level was considered to be prior by $41.8 \%$ of managers, the level of a region - by $3 \%$, of an administrative region $-29.6 \%$, of an educational institution $-23.5 \%$. In 2016 the level of state influence was estimated to equal $50 \%$, of the regional level - close to $0 \%$, but an essential increase was observed on the level of the administrative region - to $38 \%$. At the same time, the level of educational institution decreased to $12 \%$ which directly suggests a decrease in school management autonomy.

In modern Ukraine, the process of governance decentralization is being actively implemented. At the same time, the existing system of education management which is based on activity of regional education administrations as structural units of local administrations is morally outdated. This system, like the system of postgraduate pedagogical education institutes, was mainly formed within Stalinist administrativecommand system and is not democratic because it was built on repressive and command principles. Today the local community is not actually capable of influencing the district level of education management because of certain democratic mechanisms, which needs to be changed.

The existing system results in appointment by local education authorities' appointments of such managers who obediently perform their responsibilities within the boundaries set by the mayor of a city or the regional administration head. It is worth mentioning that there are cases when these positions are held by people who were responsible for this branch as district committee instructors of the Communist party of Ukraine in particular regions. If there are some positive changes on the school level, where parents' community influences some managerial decisions, the regional level is virtually unavailable for it (if we do not consider formally organized 
parents' councils of various levels).

The survey of educational institutions' managers in 2016 revealed their point of view about the election of heads of regional education boards. The views split in half $-38 \%$ for the election of this category of managers, $38 \%$ were against it, while $24 \%$ hesitated with their answer. At the same time, creation of school districts with obligatory elections of their heads by the local community is an urgent necessity of time, which is proved by many examples from worldwide experience, in particular the practice of electing heads of school counties in the USA. Another relevant actual problem for Ukraine is also renewing and professionalization of education managerial personnel on all levels, which is a prerequisite for positive change.

\section{Consequences of totalitarianism}

Another important problem of Ukrainian education is the humiliated state of the teacher and the education manager. The issue is not only about the low labor compensation. Some steps in this direction have been declared by the Ukrainian Government for the 2017 budget. There is one more complicated problem not concerning economic difficulties, which is inner freedom of teachers. One of consequences of the totalitarian Soviet system is the fact that an educator is considered by the government to be an instrument which does not have its own position and is an obedient performer of the government's will. In the Soviet times, everything possible was done to make the school and the teacher mouthpieces of Soviet ideology. Thus, illustrative is an attempt to change the population's ideology through filling the schools of West Ukraine with teachers from other regions of Ukraine and the Soviet Union (about 44,000 teachers were directed to rural schools of West Ukrainian regions in 1994-1950 only) [20].

In the recent times of Ukrainian independence, school personnel has traditionally been sent to represent interests of political parties in power at various meetings. Moreover, organizational functions in this direction have been realized on the regional level of education management. The population which has existed under totalitarianism for a long time, has developed a gene of fear. It is typical of totalitarianism and its consequences to regulate social and private life of citizens. No exception is an educator who is afraid of falling from grace and losing the job, or is afraid of some abstract punishment for disobedience. The number of educators who feel really free internally is growing slowly alongside with generation change. Thus, we have a key problem: an internally dependent citizen will never educate a free person. The responsibility of representatives of power for using education staff as political material still remains a problem in Ukraine. Nowadays it is very difficult to provide examples of direct responsibility of administrators who are involved in making decisions concerning their usage of budget employees in political actions in spite of the fact that it has been a long time since the Revolution of Dignity.

Another consequence of the totalitarian past is excessive financial centralization in education. In fact, secondary schools in Ukraine have no access to the money given to them according to the governmental subvention because the institute of centralized 
accountancy has been functioning at district offices of education since the Soviet times. Since there is a common budget, the centralized accountancy supervises not only budget, but also extrabudgetary funds which are gained by an educational institution by means of providing a certain number of educational services. Besides, these accounts contain both sponsor and charity funds, etc. Thus, further democratization of education by way of autonomous school management development is being blocked by outdated economic mechanisms. The state has not introduced modern economic mechanisms, particular voucher programs, which could substantially liven the market of education services, make it more competitive.

Ukrainian education is oppressed by other totalitarian consequences. And it is not only political pressure on the manager and the teacher. For example, one of the features of the post-totalitarian country is the so-called 'inspections' of schools which have undergone no changes since the Soviet times. The Soviet practice of using free labor of children and teachers still exists in Ukraine nowadays. In our recent past it was named 'subotniks' (communist collective unpaid voluntary work) which were held, as a rule, in April, when the birthday of the proletariat leader was celebrated. The word "communist" is changed for "ecologic" today. This process continues during all the spring months. This activity results in anti-motivation for true voluntary ecologic and other work by calling. Moreover, teachers are distracted in their spare time and entrusted with responsibility for children's lives and health, etc. A considerable part of education managers do not understand that de-communization is not only crashing monuments to V.I. Lenin and banning communist symbolics, but first of all, it is rejection of communist tradition and gaining intrinsic freedom.

\section{Conclusion}

1. An essential problem on the way to reforms in education in Ukraine is noncompliance of managerial actions in the reformation process, lack of consistency in management decision-making, excessive government centralization. Nothing but decentralization of educational management will enable local communities to exert actual influence on the quality of educational services on their territory.

2. Staff policy wants perfection, especially in the realm of educational institutions' managers appointment. An urgent task is utter deliverance from such a factor as political loyalty of an applicant; obligatory implementation of democratic procedures when making appointments which should be based on strict professional selection.

3. Economic mechanisms in education want diversification (including provision of voucher programs), which will significantly liven the market of educational services and improve education quality through implementation of market mechanisms.

4. Effective reformation of Ukrainian education is possible only through liquidation of totalitarian habits; banning communist symbols, rudimentary events and nomenclature practice from the past. 


\section{References}

1. Burdyak, V. I. Transformation in the Educational and Cultural Sphere of the PostCommunist Republic of Bulgaria. Carpathian Bulletin NTSh, 2014, No 3, p.p. 122-133.

2. Bzrezinski, Z., Bzrezinski, Ya., Bystrytskyi Y. Political Science of Post-Communism (Political Analysis of Post-Communist Societies), 1995, http://litopys.org.ua/polpost/pp.htm [2016-11-12].

3. Education Policy: Portal of Public Experts, http://education-ua.org/ua/ [2016-11-10].

4. Hromovyi, V. V. Let's Liquidate Marasmus in School Education. Marasmus No. 12. Bureaucratic Vertical of Power, 2016. http://education-ua.org/ua/articles/798likvidovuemo-marazmi-v-shkilnij-osviti-marazm-12-byurokratichna-vertikalupravlinnya [2016-11-10].

5. Lazhykha, M. I. Post-Communist Transformation: Regular Patterns and Distinctive Features in the Repiblic of Bulgaria, 2013. http://nbuv.gov.ua/UJRN/aplup_2013_2_7 [2016-11-12].

6. Lunyachek, V. Genetic Analysis of Vocational Training of Education Administrators in Master's Degree Programs in Ukraine. Public Policy and Administration, 2015, Vol. 14, No. 1, p.p. 25-39.

7. Lunyachek, V. E. Head of the District Education Department: Distinctive Features, Educational Portal, 2013. http://education-ua.org/ua/analytics/158-nachalnik-rajonnogoupravlinnya-osvitoyu-shtrikhi-do-portretu [2016-10-20].

8. Lunyachek, V. E. Improvements in Training Masters in State Management for Evaluating Education Quality on the Basis of Scientific Papers. Education in Luhansk Region, 2010, Vol. 2, No. 33, p.p. 31-39.

9. Lunyachek, V. E. Managing Education on the District Level: Reloading, School Head Master, 2015, Vol. 5, No. 101, p.p. 37-44.

10. Lunyachek, V. E. Pedagogical Management. Publishing House of KhaRI NADU: «Mahistr», 2014.

11. Lunyachek, V. E. Postgraduate Pedagogical Education: Do We Need a New Development Pattern? Education Management. Journal for Managers in Education, 2016, Vol. 3, No. 375, p.p. 22-27.

12. Lunyachek V. Problems of the Education System Development of Ukraine in Times of Crisis. Public Policy and Administration, 2011, Vol. 10, No. 1, p.p. 67-79.

13. Lunyachek, V. E. The Law «On Education»: Reflections Following Ratification after the First Reading. http://education-ua.org/ua/articles/676-zakon-pro-osvitu-refleksiya-pislyazatverdzhennya-u-pershomu-chitanni [2016-10-11].

14. Lunyachek V. Training Managerial Staff in Education Quality Management, Global, Continental, National and Regional Conditions of Local Development. Gdansk, Kharkiv: Publishing House "ADNDU”, 2014, p.p. 107 - 110.

15. Lunyachek, V. E. Training Masters in State Management to Provide Quality of Education: Theory and Practice. KhNU, 2011.

16. Lunyachek, V. E. Why Do Educational Reforms Fail in Ukraine? http://educationua.org/ua/articles/819-chomu-ne-jdut-reformi-osviti-v-ukrajini [2016-10-02]. 
17. Lyubar, O. O., Stelmakhovych, M. G., Fedorenko, D. T., History of Ukrainian School and Pedagogics: Tutorial. Publishing House «Znannya», 2006.

18. Post-Communist Transformations Baltic Countries, http://www.slideshare.net/brynetna/ss-58148172 [2016-11-11].

19. Shelomovska O., State Management of Higher Education in Post-Communist Countries of the EU: Experience for Ukraine, 2012, http://www.dridu.dp.ua/vidavnictvo/2012/2012_02(13)/12somsdu.pdf [2016-11-11].

20. Spreading the Soviet Regime in Western Regions of Ukraine, http://edufuture.biz/index.php?title=Радянізація_західних_областей_України [201610-22].

Lunyachek Vadim Eduardovich

\section{Posovietinis sindromas Ukrainos švietime: administraciniai klausimai}

Anotacija

Straipsnyje analizuojama posovietinès praeities įtaka šiuolaikiniams Ukrainos švietimo procesams. Jame pristatomi švietime dirbančio vadovaujančio personalo apklausų, atliktų per pastaruosius dešimt metų, duomenys, nagrinèjama nuomonių apie politinių faktorių įtaką, skiriant personalą švietime, dinamika. Tyrimas atskleidžia demokratizaciją ir profesinį tobulejjimą vadovaujančio personalo skyrimo procese, naujų ekonominių metodų, decentralizacijos švietimo administravime sąlygomis, bei esminių tiek vadovaujančio, tiek pedagoginio personalo pokyčių poreikį.

Lunyachek Vadim Eduardovich - Doctor of Pedagogical Sciences is a Professor and Head of Creative Pedagogy and Intellectual Property Department of Ukrainian Engineering Pedagogics Academy.

E-mail.: vel2003@ukr.net.

Lunyachek Vadim Eduardovich - pedagoginių mokslų daktastas, yra Ukrainos inžinèrinès pedagogikos akademijos, Kürybinès pedagogikos ir intelektinès nuosavybes katedros profesorius ir vedejas.

E.paštas: vel2003@ukr.net.

Straipsnis įteiktas redakcijai 2016 m. lapkričio mèn.; recenzuotas; parengtas spaudai 2017 m. sausio mèn. 